\title{
EFFECTIVE TEACHING STARTEGIES IN AN ONLINE ENVIROMENT
}

\author{
Keith Buckley \\ Director of Physical Education Rollins College (USA) \\ Winter Park Florida, USA
}

\begin{abstract}
The online classroom is a powerful teaching and learning arena in which new practices and new relationships can make significant contributions to learning. Instructors must be trained not only to use technology, but also to shift the ways in which they organize and deliver material. Making this shift can increase the potential for learners to take charge of their own learning process and facilitate the development of a sense of community. In constructing an online course, the instructor must take into account: designing the course, implementing content, facilitating learning, relevant assignments and course evaluation. A learner-centered approach acknowledges what students bring to the online classroom, their background, needs, and interests, and what they take away as relevant and meaningful outcomes. This paper will explore how to design implement and instruct a thorough online course that engages the student and gives them a platform to learn and enhance their academic experience.
\end{abstract}

\section{KEYWORDS:}

Online Learning, Education, Teaching

\section{INTRODUCTION}

In order to create an effective online course, it is very important to understand that it is for the benefit of the student and all design implementation and evaluation should be done that is in the best interests of the student. Online Learning is a mixture of learning methods that incorporate multiple teaching models. It is a natural development to the growing accessibility of eLearning, online resources and the continued need for a human component in the learning experience. An online learning approach ensures that the learner is engaged and driving his or her individual learning experience. This approach also helps cater to the individual needs of the learner; most students have unique learning styles and an online approach is more likely to cater to those needs than a traditional classroom teaching experience.Online learning is important because it breaks down the traditional walls of teaching, ones that don't work for all students and now with access to present day technologies and resources we can tailor the learning experience for each student. Online learning also offers flexible time frames that can be personalized to each person, offering them the ability to learn at their own pace. For universities, online courses can be part of a strategy to compensate for limited classroom space, as well as a way to think differently about encouraging faculty collaboration. For faculty, online courses can be a method to infuse new engagement opportunities into established courses or, for some, provide a transitional opportunity between fully face-to-face and fully online instruction. For students the conveniences of online learning combined plus their social and instructional interactions that may not lend themselves to face to face instruction. All students no matter their age learn differently, and teaching methods 
should reflect this, by designing teaching programs in a way that reaches visual, auditory and kinetic learners alike. With the heavy integration of technologies, we'll be able to improve teaching, information retention, engagement, responsibility and enjoyment. Students never outgrow their learning styles, meaning online learning is more important than ever, no matter what the industry is, from schools to corporations, in all walks of life.

When setting the course there are five basic tenants of a complete course: Interactions, Design, Content, Assessment and Evaluation. Each one is extremely important and leads the student to have well defined, organized and pedagogically centered experience.

\section{Background}

When observing the literature on online learning, it is apparent that results have not meet expectations of student learning. Administrators are much more excited than educators in the benefits of Online learning. A 2014 department of education study reported: "The proportion of chief academic leaders reporting online learning is critical to their long-term strategy reached a new high of 70.8 percent. At the same time, only 28 percent of academic leaders say that their faculty accepts the 'value and legitimacy of online education.' Online education is the fastestgrowing segment of higher education and its growth is overrepresented in the for-profit sector. Despite this faculty and academic leaders, employers and the general public are skeptical about the quality and value of online education, which they view as inferior to face-to-face education. Students in online education, particularly underprepared and disadvantaged students, have consistently underperformed and on average experience poor outcomes. Very surprisingly Online education has failed to improve affordability, frequently costs more than in-person alternatives and has not produced a positive return on investment. Regular and substantive student-instructor interactivity is a key determinant of quality in online education, leading to improved student satisfaction, learning and outcomes.

\section{INTERACTIONS}

This area clearly explains to the student all the necessary information about times, assignment's, expectations and protocols. In order to learn any academic subject students, need to interact and even struggle with the material being learned (called active learning). Pre-classroom assignments are set, and students are asked to explain concepts and ideas to their peers in class. The online component allows students to work at their own speed, but it should force them to research, reflect and discuss complex issues within the course. The assigned work should tie in with the course goals and objectives.

When developing the course schedule topics and assignment should be distributed evenly. The course schedule also helps students know from Day 1 the exam and due dates, as well as plan their reading to be prepared for online discussions. The official syllabus of most schools is very long with details and policies as required by institutional policy. A way to help the students is to create a mini syllabus to provide quick access to the most important aspects of the course. The syllabus should outline objectives and learning outcomes. It should give students resources for disabilities, technology help and relevant institutional information.

Protocols is a document detailing course expectations and norms. In class preparation, E mail correspondence and online discussions are all discussed. This is where all technical support such as $\log$ in procedure and course requirements are stated such as student responsibilities in the classroom and online are stated. Also, the consequences of late/missed assignments. The module interaction allows the alignment of the unit learning objectives with assessment and interaction 
activities. The teacher has to carefully consider how to design each week of the course, combining different content resources with faculty-student and student-student interaction activities that foster a sense of community and critical thinking, with formal and informal formative assessments.

There are of course many different technological tools. It is vital that the teacher designs' the course around technology that he/she is comfortable with and will aid the student in their learning process and not hinder it. Tools such as Google Docs, Edpuzzle, Padlett and Kahoot. Kahoot is especially effective as you can test students individually or in teams that compete against each other in their comprehension of the class that day. Each of the tools listed has its own functionalities, but all are beneficial when it comes to one crucial aspect of modern schooling: they pave the way for re-examination of the current learning methodologies. These tools open up the space for dialogue on the potential that technological devices can bring to today's learning environments.

In the majority of classes, interaction across all forms is vital. This gives the student a sense of belonging and that the course is important. The more effective interaction the more motivated the student will most likely be. Positive interaction will enhance the learning environment in all kinds of courses. The benefits of an online format allow students to work at their own speed and time in the online format and therefore in the classroom this can maximize in class discussion. This gives students the ability to understand other student's viewpoints and ideas. The teacher's responsibility is to facilitate this discussion and make it relevant to the modules of the course

\section{DESIGN}

Successful online courses start with effective planning for overall design and outcomes. By identifying your course goals and learning objectives, you achieve a clearer picture of how to best design a structured and engaging course. A strong understanding of the needs of your learners and how your course can meet those needs is important to the success of your course delivery. Therefore, it is essential to consider what you want your student outcomes to be at the conclusion of your online course.

It is obviously important to have an effective design that makes learning intuitive and stimulating. The quote "The focus should be first on the learning, and second on the technologies that will support that learning" is very profound. Different schools have various ways of approaching online learning and the design of the course must fit the mission of the institution. The course should focus on teaching and learning in a very collaborative and informative manner. Discussion and debate are very important parts of the curriculum. If an institution's online learning strategy can be designed to address the needs and dynamics of all three constituencies (institution, faculty, and student) simultaneously, then online learning can become a powerful force for institutional transformation. With the right design and strong learning objectives the students will embrace online learning and it will be a major addition to the curriculum.

Course objectives, instructional strategies, content, and assignments should facilitate learners to attain the course goals. The instructor needs to understand the characteristics of the students in terms of what types of learning are involved. Also, what content and information is needed to facilitate learning, and what tasks do learners need to master to achieve the overall course goals. The instructor needs to have a logical sequence of content and activities, and an awareness of what technologies are available and best suited to present the content to facilitate learning. Functioning as guideposts, learning objectives help students organize their efforts toward accomplishing the desired behaviors. Learning objectives also help the instructor identify whether students have gained the appropriate skills and knowledge. A learning objective is a 
statement that: specifies in measurable terms what a learner will be able to do as a result of your instruction; describes the intended outcome of the course rather than a description or summary of the content and details the intended results rather than the means of achieving the results.

Enhancing the course with learning objects and activities will help to communicate course content beyond static readings and lectures. Content presented in a memorable and meaningful way will stimulate the learner making the course more dynamic and successful.

\section{Content}

It is vital to stay current with effective online teaching strategies for designing, implementing, and facilitating the course. As the author of an online course, the course content may include text, music, graphics, illustrations, articles, photographs, etc. Some of the content you wish to use may be protected by copyright law. Implementing content needs to be predictably. Write detailed, sensible policies and consistent information to help create predictability from the student's perspective. The content should be organized to provide students guidance about how to use the course management tools effectively (e.g., threaded discussions, assignments, quizzes, etc.). The instructor should be prepared to know the syllabus, resources, and learner support systems to respond to students' questions timely and completely. Resourcefulness and planning are important to Identify alternative plans for delivering the course in the event of technology issues or modifying activities if students are not "getting it". Lastly the Instructor needs to be responsive to Counteract the negative aspects of the distance separating the instructor and the students. This can be done by monitoring the online courses frequently and responding to student concerns in a timely manner.

\section{FACILITATING Learning}

In an online classroom, flipping can work in a number of ways. Consider, for example, assigning students to complete a particular reading or lesson. An online discussion can begin where learners are encouraged to delve deeper into the lesson, pose questions, and share their own unique interpretations. This method creates a more diversified learning environment and foster a deeper understanding of the subject matter being discussed. Mind mapping is probably one of the best online teaching techniques to implement for the visual learners within a class. A mind map is a diagram of related ideas and concepts that can be used as an aid for studying, a way of organizing information or even a springboard for a writing assignment. This helps instructors in structuring classroom discussions, classifying ideas and gradually bringing learners to the central idea. The aim is to uncomplicate complex concepts or issues. The benefits for learners are that it's quick, easy and allows them to "dive right in" the ideas around a central concept and connecting the dots to reach the central idea. In an online course, you can have students create their own mind maps (either on paper or using online mapping software) and share them with the rest of the class, allowing for easier sharing of ideas and interpretations. Mind mapping is ideal for making connections between ideas/concepts, planning out projects or written assignments and a better understanding the learning material Yet another concept to implement is that of promoting selflearning in a controlled environment. With self-learning, students are encouraged to explore certain subject matter and decide what aspects are most important or relevant to their own interests. Self-learning is a great way to get learners truly invested in the subject matter in ways that apply to real-life situations. The concept of instructional design is a teaching technique that refers to designing your classroom around your learners' unique backgrounds and your ultimate goals (or what you want students to take away from the course). The technique is not restricted for the use in on-site setting, rather it's equally important in an online learning setting, where 
learners have very unique backgrounds and bring a different set of experiences to the table (especially when compared with "traditional" face-to-face classrooms).

As such, instructional design means taking the time to get a better understanding of the learners. What is their current understanding of the subject matter? What are their different learning styles? In simplest terms, instructional design recognizes that there's no "one-size-fits-all" approach to teaching. Adaptive learning involves utilizing computers and other technologies as viable teaching devices. As an online instructor, adaptive learning will inherently come into play, but it's up to the teacher to make the most of the technology available to themselves and their students. For some students, learning a particular subject by watching a video may be most effective. Others may learn better through participating in online discussion forums. Ultimately, it's up to the teacher to transform each student from a passive receptor of information into a willing and active participant in the online classroom. This may mean providing different mediums (video, text, visuals, etc.) for introducing each new lesson or concept.

\section{ASSESSMENT}

It is crucial to provide clear instructions for all assignments, as well as exam objectives, to help students focus, have a clear understanding of expectations and how the assignments help ful fill course objectives. Written, clear instructions also help faculty minimize students' questions about what to do, when is the assignment due or how is it going to be marked. Part of the process is developing a scoring rubric. This can be a tedious, but it helps the teacher mark assignments consistently and students know how they're going to be evaluated and why they lost points. Formal and informal formative and summative assessment are extremely important in the development of a course. Online assessments are quite personal, and the student gets from it the level of work that they put in. In face to face classroom assessments the student's personalities are much more evident but sometimes one or two verbally strong students can dictate the class. Carefully assigned projects and discussion boards can create a much fairer and less obtrusive form of class participation that is transparent and equal.

\section{Evaluation}

How will the instructor know if the course met the learning goals and was effective? Many evaluations are done right at the end of the class/semester when students are more concerned with finals as opposed to a serious reflection of the class. Like many things as long as we grow in our learning each class should be more productive than the last and by building on a foundation of good teaching practices this should occur. It is advisable to have a colleague evaluate the formatting and design of the course and make comments. It is not easy to share with your peers and the teacher has to be able to take constructive criticism, but it is a very valuable tool. The class needs to intuitive to a student, many teachers just assume the students understand what the teacher is thinking. To determine the quality of the course and its levels of success is hard to define in a learning environment. Success maybe having a class that those students who struggle with a traditional format find more appealing and their motivation to complete the class is enhanced. Quality is having best teaching practices best learning practices and the ability to effectively communicate with the students. The key for having a quality online learning class that is well received by the students doing the research and applying simple design rules. The content, the application of the content and then analyzing the content is the way for any class to be successful. Peer review is a very easy yet significant way of making sure you are on task with your course. Student evaluations are a critical component but sometimes they do offer a shortterm reflection. 


\section{MOVIng ForWARD}

Online courses have expanded rapidly and have the potential to extend further the educational opportunities of many students, particularly those least well-served by traditional educational institutions. By harnessing emerging technologies, universities can reach beyond campus walls to empower diverse learners at global scale. However, in their current design, online courses are difficult, especially for the students who are least prepared. Continued improvement of online curricula and instruction can strengthen the quality of these courses and hence the educational opportunities for the most in-need populations. Currently these students' learning and persistence outcomes are worse when they take online courses than they would have been had these same students taken in-person courses. It begins with embracing stackable, online learning, which provides flexibility and affordability that increases access to university curricula and allows students to engage in smaller chunks of learning before committing to larger degree programs.

\section{CONCLUSION}

An online course isn't simply throwing in some PowerPoint presentations, assigned textbook readings, weekly quizzes and exams. The content must be balanced, clear, engaging and diverse. Given the nature of the course, communication is important. Students shouldn't be abandoned, and an effort must be made to both give them the assistance they need and create a sense of community between the students. Assessment activities are more than quizzes and exams. Learning management systems provide a plethora of assessment activities, such as discussion forums, peer reviews, collaborative wikis and other group projects. Assessment needs to go beyond measuring cognitive learning and include other aspects such as the development of affective skills (i.e., working in group projects or integrating use of technology in the assignments). It is imperative that an online or online learning course is organized and has an attractive, accessible design. This means that universal design for learning guidelines should be incorporated into the design. Though it can be tricky, accessibility must be ensured for all students, including those that may have some form of disability. Furthermore, students must be able to easily navigate course content and identify graded assignments to ensure the best learning environment. All legal and ethical aspects must be followed to the law. The only way these can be successfully accomplished is by the institution providing concrete support to the faculty and giving students the right to dispute these standards in a very tolerant atmosphere. When these tools are used effectively the student will be in a very healthy learning environment that is intuitive and encourages growth.

\section{REFERENCES}

[1] Allen, I. Elaine, Jeff Seaman, Russell Poulin, and Terri Taylor Straut (2016). Online Report Card: Tracking Online Education in the United States. Babson Park, MA: Babson Survey Research Group and Quahog Research Group, LLC.

[2] Anderson, T. \& Elloumi, F. (2004). Theory and practice of online learning. Athabasca: Athabasca University.

[3] Bates, A. W. \& Poole, G. (2003). Effective teaching with technology in higher education: Foundations for success. San Francisco: Jossey-Bass.

[4] Bawa, Papia (2016). "Retention in Online Courses: Exploring Issues and Solutions-A Literature Review," SAGE Open, 1-11.

[5] Belsky L (October 04, 2019). Where Online Learning Goes Next. Havard Business Review. Retrieved from https://hbr.org/2019/10/where-online-learning-goes-next

[6] Bettinger E and Loeb S Friday, June 9, 2017. Promises and pitfalls of online education. Retrived from https://www.brookings.edu/research/promises-and-pitfalls-of-online-education/

[7] Bettinger, E., Fox, L., Loeb, S., \& Taylor, E. (2017). Changing Distributions: How Online College Classes Alter Student and Professor Performance. AmericanEconomic Review. 
[8] Brown, J.S. (2013). Learning in and for the 21st century. In E. Low (Ed.), CJ Koh Professorial Lecture Series. Singapore: National Institute of Education/Nanyang Technological University. Retrieved from http://www.johnseelybrown.com/CJKoh.pdf

[9] Carman, J.M. (October, 2002). Blended learning design: five key elements. Agilant Learning. Retrieved from http://www.agilantlearning.com/pdf/Blended\%20Learning\%20Design.pdf

[10] Dietz-Uhler, B. and Hurn, J.(2011). Academic dishonesty in online courses. In Smith, P. (Ed.) Proceedings of the 2011 ASCUE Summer Conference. Myrtle Beach, SC. Retrieved from http://www.ascue.org/files/proceedings/2011-final.pdf

[11] Fain Paul. Jan 16 2019. Online learning fails to deliver. Highered. Retrieved from https://www.insidehighered.com/digital-learning/article/2019/01/16/online-learning-fails-deliverfindsreport- aimed-discouraging

[12] Hoffman, B. and Lowe, D. (2011, January). Effective online assessment: Scalable success strategies. In Faculty Seminars in Online Teaching. Seminar series conducted at the University of Central Florida, Orlando, FL. Retrieved from https://online.ucf.edu/faculty-seminar01/

[13] Lieberman, Mark (2018, July 18). Keeping Online Courses Fresh: Valuable but Costly. Inside Higher Ed. Retrieved from https://www.insidehighered.com/digital-learning/article/2018/07/18/maintainingonlinecourses- maturity-requires-substantial

[14] Littlefield, Jamie. Mar. 15, 2019. What Does Research Say About Online Learning? ThoughtCo. Retrieved from thoughtco.com/what-research-says-about-online-learning-1098012.

[15] Littlejohn, A. and Pegler, C. (2007). Preparing for blended e-learning. Routledge, LONDON: UK

[16] Mitra, S. (2007, June). Technology and higher education — Pedagogy for self organised learning systems. Paper presented at Future of Education Online Conference. Retrieved from https://sas.elluminate.com/site/external/jwsdetect/playback.jnlp?psid=2007-0604.0738.M.BB2E854755AAFFF4E1A3E2523C4E54.vcr

[17] Riley, J.E., Gardner, C., Cosgrove, S., Olitsky, N., O’Neil, C., and Du, C. (2014). Implementation of blended learning for the improvement of student learning, In A. Picciano, C. Dziuban, and C. Graham (Eds.), Blended learning: Research perspectives, volume 2. NY: Routledge.

[18] Spiros Protopsaltis and Sandy Baum ${ }^{i}$ January 2019 Does Online education Live Up to its Promise?A look at the evidence and implications for federal policy. Retrieved from http://mason.gmu.edu/ sprotops/OnlineEd.pdf

[19] U.S. Department of Education (2016). "Introduction to Competency-Based Education," CBE Experiment Guide.

\section{AUTHOR}

\section{Dr. Keith Buckley}

Dr. Buckley is a Professor who has taught in the Health and Physical Education department for the last 15 years at Rollins College. . He earned his Doctorate in Education from the University of Central Florida in 2003 specializing in Instructional technology. He holds a master's in business administration from the Crummer School of Business at Rollins College (1995) and earned his undergraduate degree from Rollins College. He is the Director of Physical Education at Rollins College and serves on the the Health and Wellness committee for the college. He holds the Greene Chair which was established in 1967 by Raymond W. Greene, who stipulated that the chair-

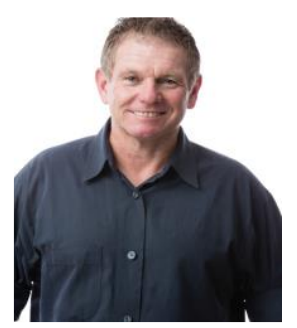
holder should encourage reverence for the "Amazing Creation of the Human Body and Its Functions." He also is the soccer coach of the college and has accumulated over 300 wins in his coaching tenure.

(C) 2020 By AIRCC Publishing Corporation. This article is published under the Creative Commons Attribution (CC BY) license. 